\title{
RETHINKING THE CONCEPT OF LONG-RUN ECONOMIC GROWTH
}

\author{
CHRISTIAN GROTH \\ KARL-JOSEF KOCH \\ THOMAS M. STEGER
}

CESIFO WORKING PAPER NO. 1701

CAtegory 5: Fiscal Policy, Macroeconomics AND Growth APRIL 2006

\footnotetext{
An electronic version of the paper may be downloaded

- from the SSRN website:

wWw.SSRN.com

- from the RePEc website:

Www.RePEc.org

- from the CESifo website:

www.CESifo-group.de
} 


\title{
RETHINKING THE CONCEPT OF LONG-RUN ECONOMIC GROWTH
}

\author{
Abstract \\ This paper argues that growth theory needs a more general "regularity" concept than that of \\ exponential growth. This offers the possibility of considering a richer set of parameter \\ combinations than in standard growth models. Allowing zero population growth in the Jones \\ (1995) model serves as our illustration of the usefulness of a general concept of "regular \\ growth". \\ JEL Code: O31, O40, O41. \\ Keywords: exponential growth, arithmetic growth, regular growth, semi-endogenous growth, \\ knife-edge restrictions. \\ Christian Groth \\ Department of Economics \\ University of Copenhagen \\ Denmark \\ chr.groth@econ.ku.dk \\ Karl-Josef Koch \\ Department of Economics \\ University of Siegen \\ Germany \\ koch@vwl.wiwi.uni-siegen.de \\ Thomas M. Steger \\ ETH Zurich \\ WIF - Institute of Economic Research \\ ETH Center, ZUE F 13 \\ 8092 Zurich \\ Switzerland \\ tsteger@ethz.ch
}

March 2006

For helpful comments and suggestions we would like to thank Hannes Egli, Sebastian Krautheim and Holger Strulik. 


\section{Introduction}

The concept of balanced growth, generally synonymous with exponential growth, has proved extremely useful in the theory of economic growth. This is not only because of the historical evidence (Kaldor's "stylized facts"), but also because of its convenient simplicity. Yet there may be a deceptive temptation to oversimplify and ignore other possible growth patterns. We argue there is a need to allow for a richer set of parameter constellations than in standard growth models and to look for a more general "regularity" concept than that of exponential growth. The motivation is the following:

First, when setting up growth models researchers place severe restrictions on preferences and technology such that the resulting model is compatible with balanced growth. For instance, models exhibiting balanced growth usually rely on some form of knife-edge restrictions, which drastically restrict the shape of preferences and production technology (Solow, 2000, Chapters 8-9). This paper demonstrates that regular long-run growth, in a sense specified below, can arise even if these restrictions are violated.

Second, standard R\&D-based semi-endogenous growth models imply that the long-run per-capita growth rate is proportional to the growth rate of the labor force (Jones, 2005). This class of models is frequently used for positive and normative analysis since it appears to be empirically plausible in many respects. If we employ this type of model to evaluate the prospect of growth in the very long run, then we end up with the assertion that the growth rate converges to zero. This is simply due to the fact that there must be limits to population growth. But then, what does this really imply for economic development in the very long run? This question has not received much attention so far and the answer is not that clear at first glance.

Third, everything less than exponential growth often seems interpreted as a fairly bad outcome and associated with economic stagnation. For instance, in the context of the Jones (1995) model with constant population, Young (1998, n. 10) states "Thus, even if there are intertemporal spillovers, if they are not large enough to allow for constant growth, the development of the economy grinds to a halt." However, to our knowledge, the case of zero population growth in the Jones model has not really been explored yet. We take the opportunity to let an analysis of this case serve as our illustration of the usefulness of the general concept of regular growth.

The paper is structured as follows. Section 2 introduces our regularity concept and shows how it is related to the cases of exponential and arith- 
metic growth. Section 3 illustrates that allowing a richer set of parameter combinations than in standard growth models indeed gives rise to other regularity patterns than exponential growth. Finally, Section 4 summarizes the findings.

\section{Regular Growth}

Growth theory explains long-run economic development as some pattern of regular growth. The most common regularity concept is that of exponential growth. Occasionally another regularity pattern turns up, namely that of arithmetic growth. Indeed, a Ramsey growth model with AK technology and CARA preferences features arithmetic GDP per capita growth (e.g., Blanchard and Fischer, 1989, pp. 44/45). Similarly, under Hartwick's rule, a model with essential non-renewable resources features arithmetic growth of capital (Solow, 1974; Hartwick, 1977). In similar settings with nonrenewable resources Mitra (1983), Pezzey (2004) and Asheim et al. (2005) consider growth paths of the form $x(t)=x(0)(1+\mu t)^{\omega}, \mu, \omega>0$, which, by the last-mentioned authors, is called "quasi-arithmetic growth". In these analyses the quasi-arithmetic growth pattern is associated with exogenous quasi-arithmetic growth in either population or technology. In this way results by Dasgupta and Heal (1979, pp. 303-308) on optimal growth within a classical utilitarian framework with non-renewable resources, constant population and constant technology are extended.

In our view there is a rationale for a concept of regular growth, subsuming exponential growth and arithmetic growth as well as the whole range between these two. Also some kind of less-than-arithmetic growth should be included. This general concept is labelled regular growth, for reasons that will become clear below. The example we consider in Section 3 shows how a quasi-arithmetic growth pattern may arise endogenously in a two-sector knowledge-driven growth model.

To describe our suggested concept of regular growth, a few definitions are needed. Let the variable $x(t)$ be a positively-valued differentiable function of time $t$. Then the growth rate of $x(t)$ at time $t$ is:

$$
g_{1}(t):=\frac{\dot{x}(t)}{x(t)},
$$

where $\dot{x}(t):=d x(t) / d t$. We call $g_{1}(t)$ the first-order growth rate. Since we seek a more general concept of regular growth than exponential growth, we 
allow $g_{1}(t)$ to be time-variant. Indeed, the regularity we look for relates precisely to the way growth rates change over time. Presupposing $g_{1}(t)$ is strictly positive within the time range considered, let $g_{2}(t)$ denote the second-order growth rate of $x(t)$ at time $t$, i.e.,

$$
g_{2}(t):=\frac{\dot{g}_{1}(t)}{g_{1}(t)}
$$

We suggest the following criterion as defining regular growth:

$$
g_{2}(t)=-\beta g_{1}(t) \quad \forall t \geq 0,
$$

where $\beta \geq 0$. That is, the second-order growth rate is proportional to the first-order growth rate with a non-positive factor of proportionality. The coefficient $\beta$ is called the damping coefficient, since it indicates the rate of damping in the growth process.

Let $x_{0}$ and $\alpha$ denote the initial values $x(0)>0$ and $g_{1}(0)>0$, respectively. The unique solution of the second-order differential equation (1) may then be expressed as:

$$
x(t)=x_{0}(1+\alpha \beta t)^{\frac{1}{\beta}} .
$$

Note that this solution has at least one well-known special case, namely $x(t)=x_{0} e^{\alpha t}$ for $\beta=0 .{ }^{1}$ Moreover, it should be observed that, given $x_{0},(2)$ is also the unique solution of the first-order equation:

$$
\dot{x}(t)=\alpha x_{0}^{\beta} x(t)^{1-\beta}, \quad \alpha>0, \beta \geq 0,
$$

which is an autonomous Bernoulli equation. This gives an alternative and equivalent characterization of regular growth.

The simple formula (2) describes a family of growth paths, the members of which are indexed by the damping coefficient $\beta$. Figure 1 illustrates this family of regular growth paths. ${ }^{2}$ There are three well-known special cases. For $\beta=0$, we have $g_{1}(t)=\alpha$, a positive constant. This is the case of exponential growth. At the other extreme we have complete stagnation, i.e., the constant path $x(t)=x_{0}$. This can be interpreted as the limiting case $\beta \rightarrow \infty .{ }^{3}$ Arithmetic growth, i.e., $\dot{x}(t)=\alpha, \forall t \geq 0$, is the special case $\beta=1$.

\footnotetext{
${ }^{1}$ Indeed, $\lim _{\beta \rightarrow 0} x_{0}(1+\alpha \beta t)^{\frac{1}{\beta}}=x_{0} e^{\alpha t}$. To see this, use L'Hôpital's rule for " $0 / 0$ " on $\ln (x(t))=\ln \left(x_{0}\right)+\frac{1}{\beta} \ln (1+\alpha \beta t)$.

${ }^{2}$ Figure 1 is based on $\alpha=0.05$ and $x_{0}=1$. In this case, the time paths do not intersect. Intersections occur for $x_{0}<1$. However, for large $t$ the picture always is as shown in Figure 1.

${ }^{3}$ Use L'Hôpital's rule for " $\infty / \infty$ " on $\ln x(t)$. If we allow $g_{1}(0)=0$, stagnation can of course also be seen as the case $\alpha=0$.
} 


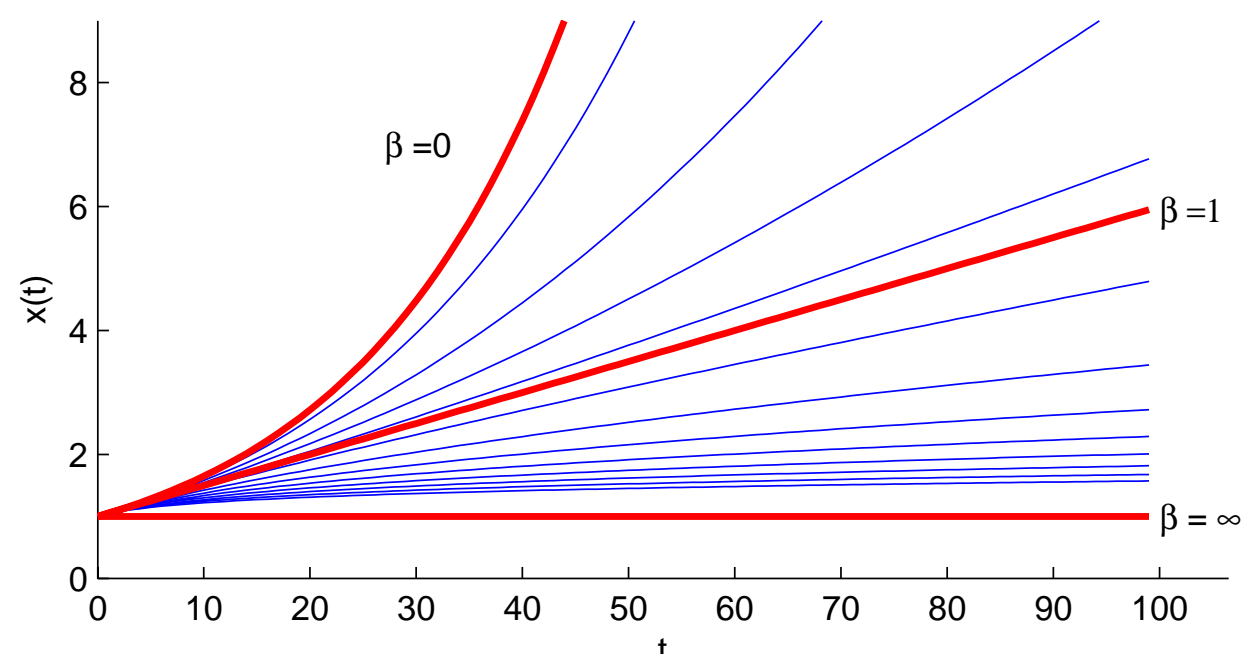

Figure 1: A family of growth paths indexed by $\beta$.

Table 1 lists these three cases and gives labels also to the intermediate ranges for the value of the damping coefficient $\beta$. Apart from being written in another (and perhaps less family-oriented) way, the "quasi-arithmetic growth" formula in Asheim et al. (2005) mentioned above, is subsumed under these intermediate ranges.

Table 1: Regular growth paths: $g_{2}(t)=-\beta g_{1}(t) \forall t \geq 0, \beta \geq 0, g_{1}(0)>0$.

\begin{tabular}{|c|c|c|}
\hline Label & $\begin{array}{c}\text { Damping } \\
\text { coefficient }\end{array}$ & Time path \\
\hline \hline Limiting case 1: exponential growth & $\beta=0$ & $x(t)=x_{0} e^{\alpha t}, \alpha>0$ \\
\hline More-than-arithmetic growth & $0<\beta<1$ & $x(t)=x_{0}(1+\alpha \beta t)^{\frac{1}{\beta}}, \alpha>0$ \\
\hline Arithmetic growth & $\beta=1$ & $x(t)=x_{0}(1+\alpha t), \alpha>0$ \\
\hline Less-than-arithmetic growth & $1<\beta<\infty$ & $x(t)=x_{0}(1+\alpha \beta t)^{\frac{1}{\beta}}, \alpha>0$ \\
\hline Limiting case 2: stagnation & $\beta=\infty$ & $x(t)=x_{0}$ \\
\hline
\end{tabular}

As to the case $\beta>1$, notice that though the increase in $x$ per time unit is falling over time, it remains positive; there is sustained growth in the sense that $x(t) \rightarrow \infty$ for $t \rightarrow \infty$. $^{4}$ Formally, also the case of $\beta<0$ (more-thanexponential growth) could be included in the family of regular growth paths.

\footnotetext{
${ }^{4}$ Empirical investigation of post-WWII GDP per-capita data of a sample of OECD countries yields non-negative damping factors between 0.17 (UK) and 1.43 (Germany). The associated initial (annual) growth rates in 1951 are $2.3 \%$ (UK) and $12.4 \%$ (Germany), respectively. The fit of the regular growth formula is remarkable.
} 
However, this case should be considered as only relevant for a description of possible phases of transitional dynamics. A growth path (for, say, GDP per capita) with $\beta<0$ is explosive in a very dramatic sense: it leads to infinite output in finite time (Solow, 1994).

\section{An Example}

An optimal growth problem within the simple Jones (1995) framework is considered in order to illustrate how the regularities described above may arise. Population $L$ is governed by $L=L(0) e^{n t}$, where $n \geq 0$ is constant. We include the case $n=0$ not only for theoretical reasons, but also because it is of practical interest in view of the projected stationarity of the population of developed countries as a whole already from 2005 (United Nations, 2005). ${ }^{5}$ Technologically the economy is described by:

$$
\begin{aligned}
Y & =A^{\sigma} K^{\alpha}(u L)^{1-\alpha}, \quad \sigma>0,0<\alpha<1 \\
\dot{K} & =Y-c L, \quad K(0) \text { given, } \\
\dot{A} & =\gamma A^{\varphi}(1-u) L, \quad \gamma>0, \varphi \leq 1, \quad A(0) \text { given, }
\end{aligned}
$$

where $Y$ is aggregate manufacturing output (net of capital depreciation), $A$ society's stock of "knowledge", $K$ society's capital, $u$ the fraction of the labour force (= population) employed in manufacturing and $c$ per-capita consumption; $\sigma, \alpha, \gamma$ and $\varphi$ are constant parameters. The criterion functional of the social planner is:

$$
U_{0}=\int_{0}^{\infty} \frac{c^{1-\theta}-1}{1-\theta} L e^{-\rho t} d t,
$$

where $\theta>0$ and $\rho \geq 0$, both constant. In the spirit of Ramsey (1928) we include the case $\rho=0$, since giving less weight to future generations than to current might be deemed "ethically indefensible". When $\rho=0$, there exist feasible paths for which the integral $U_{0}$ does not converge. In that case our optimality criterion is the catching-up criterion, see Case 4 below. The social planner chooses a plan $(c, u)_{t=0}^{\infty}$, where $c>0$ and $u \in[0,1]$, to optimize $U_{0}$ under the constraints (4), (5) and (6) as well as $K \geq 0$ and $A \geq 0, \forall t \geq 0$.

\footnotetext{
${ }^{5}$ From now, the explicit timing of the variables is suppressed when not needed for clarity.
} 
Case 1: $\varphi=1, \rho>n=0$. This is the fully-endogenous growth case considered by Romer (1990). ${ }^{6}$ An interior optimal solution converges to exponential growth with growth rate $\left.g_{c}=(1 / \theta)[\sigma \gamma L /(1-\alpha)-\rho)\right]$ and $u$ $=1-(1-\alpha) g_{c} /(\sigma \gamma L)$.

Case 2: $\varphi<1, \rho>n>0$. This is the semi-endogenous growth case considered by Jones (1995). An interior optimal solution converges to exponential growth with growth rate $g_{c}=n /(1-\varphi)$ and $u=\frac{(\sigma /(1-\alpha))(\theta-1) n+(1-\varphi) \rho}{(\sigma /(1-\alpha)) \theta n+(1-\varphi) \rho} .7$

Case 3: $\varphi<1, \rho>n=0$. In this case the economy can be shown to end up in stagnation (constant $c$ ), as is indicated by putting $n=0$ in the formula for $u$ in Case 2. The explanation is the combination of a) no population growth to countervail the diminishing marginal returns to knowledge $(\partial \dot{A} / \partial A \rightarrow 0$ for $A \rightarrow \infty)$, and b) a positive constant rate of time preference.

Case 4: $\varphi<1, \rho=n=0$. Depending on the values of $\varphi, \sigma, \alpha$ and $\theta$, a continuum of dynamic processes emerges which fill the whole range between stagnation and exponential growth. ${ }^{8}$ Since this case does not seem investigated in the literature, we shall spell it out here. The optimality criterion is the catching-up criterion: a feasible path $(\hat{K}, \hat{A}, \hat{c}, \hat{u})_{t=0}^{\infty}$ is catching-up optimal if

$$
\lim _{t \rightarrow \infty} \inf \left(\int_{0}^{t} \frac{\hat{c}^{1-\theta}-1}{1-\theta} d \tau-\int_{0}^{t} \frac{c^{1-\theta}-1}{1-\theta} d \tau\right) \geq 0
$$

for all feasible paths $(K, A, c, u)_{t=0}^{\infty}$.

Let $p$ be the shadow price of knowledge in terms of the capital good. Then, the value ratio $x \equiv p A / K$ is capable of being stationary in the long run. Indeed, as shown in the appendix, the first order conditions of the problem lead to:

$$
\dot{x}=\frac{\gamma L A^{\varphi-1}}{1-\alpha}\{(\alpha-s) x u-[\sigma+(1-\alpha)(1-\varphi)] u+(1-\alpha)(1-\varphi)\} x,
$$

where $s$ is the saving rate $=1-c L / Y$; further,

$$
\dot{u}=\frac{\gamma L A^{\varphi-1}}{1-\alpha}\left[-(1-s) x u+\sigma u+\frac{1-\alpha}{\alpha} \sigma\right] u, \quad \text { and }
$$

\footnotetext{
${ }^{6}$ Contrary to Romer (1990), though, we allow $\sigma \neq 1-\alpha$ for reasons explained in Alvarez-Pelaez and Groth (2005).

${ }^{7}$ The Jones (1995) model also includes a negative duplication externality in R\&D, which is not relevant for our discussion. Convergence of this model is shown in Arnold (2006).

${ }^{8}$ The entire spectrum of regular growth patterns can alternatively be obtained in an elementary version of the Jones (1995) model with no capital, but two types of (immobile) labor, i.e., unskilled labour in final goods production and skilled labour in R\&D.
} 
$\dot{s}=\frac{\gamma L A^{\varphi-1}}{1-\alpha}\left[-\left(\frac{1}{\theta}-s\right) \alpha x u-(1-\alpha) \sigma u+(1-\alpha) \sigma+\frac{(1-\alpha)^{2} \dot{u} / u}{\gamma L A^{\varphi-1}}\right](1-s)$.

Provided $\theta>1$, this dynamic system has a unique stationary state:

$x^{*}=\frac{\sigma \theta}{\alpha(\theta-1)}>0, u^{*}=\frac{\sigma+\alpha(1-\varphi)}{\frac{\theta}{\theta-1} \sigma+\alpha(1-\varphi)} \in(0,1), s^{*}=\frac{\sigma+1-\varphi}{\theta\left[\frac{\sigma}{\alpha}+1-\varphi\right]} \in\left(0, \frac{1}{\theta}\right)$.

The resulting paths for $A, K, Y$ and $c$ feature regular growth with positive damping coefficient:

$$
A(t)=\left[A(0)^{1-\varphi}+(1-\varphi) \gamma\left(1-u^{*}\right) L t\right]^{\frac{1}{1-\varphi}}=A(0)(1+\mu t)^{\frac{1}{1-\varphi}}
$$

where $\mu \equiv(1-\varphi) \gamma\left(1-u^{*}\right) L A(0)^{\varphi-1}>0$;

$$
\begin{aligned}
& K(t)=\left(\frac{1-\alpha}{\gamma x^{*}\left(u^{*} L\right)^{\alpha}}\right)^{\frac{1}{1-\alpha}} A(0)^{\frac{\sigma+1-\varphi}{1-\alpha}}(1+\mu t)^{\frac{\sigma+1-\varphi}{(1-\alpha)(1-\varphi)}} \\
& Y(t)=\left(u^{*} L\right)^{\frac{1-2 \alpha}{1-\alpha}}\left(\frac{1-\alpha}{\gamma x^{*}}\right)^{\frac{\alpha}{1-\alpha}} A(0)^{\frac{\sigma+\alpha(1-\varphi)}{1-\alpha}}(1+\mu t)^{\frac{\sigma+\alpha(1-\varphi)}{(1-\alpha)(1-\varphi)}}
\end{aligned}
$$

Finally, $c(t)=\left(1-s^{*}\right) Y(t) / L .^{9}$

When $0<\varphi<1$ (the "standing on the shoulders" case), the damping coefficient $\beta=1-\varphi<1$, i.e., knowledge features more-than-arithmetic growth. When $\varphi<0$ (the "fishing out" case), the damping coefficient is $1-\varphi>1$, and knowledge features less-than-arithmetic growth. In the intermediate case, $\varphi=0$, knowledge features arithmetic growth. ${ }^{10}$ More interesting is perhaps the path of $Y$ to which the path of $c$ is proportional. We see that $Y$ features more-than-arithmetic growth if and only if $\sigma>(1-$ $2 \alpha)(1-\varphi)$. A sufficient condition for this is that $\frac{1}{2} \leq \alpha<1$; it is interesting that $\varphi>0$ is not needed. Notice also that the capital-output ratio features arithmetic growth always, i.e., independently of the size relation between the parameters. Indeed, $K / Y=[K(0) / Y(0)](1+\mu t)$. This is like in Hartwick's rule (Hartwick, 1977). A mirror image of this is that the marginal product of capital always approaches zero for $t \rightarrow \infty$, a property not surprising in view of $\rho=0$.

\footnotetext{
${ }^{9}$ The usual transversality conditions require $\theta>(\sigma+1-\phi) /[\sigma+\alpha(1-\phi)]$, which we assume satisfied (see the appendix). This condition is slightly stronger than the requirement $\theta>1$.

${ }^{10}$ The coefficient $\mu$ could be called the growth momentum.
} 


\section{Summary and Conclusion}

Our proposed concept of regular growth has the following advantages: (1) The concept allows researchers to get rid of the largely arbitrary knifeedge restriction, which underlies both standard neoclassical and endogenous growth models. (2) Since the resulting dynamic process has one more degree of freedom compared to exponential growth, it is at least as plausible in empirical terms. (3) The concept covers a continuum of dynamic processes which fill the whole range between exponential growth and complete stagnation, a range which may deserve more attention in view of the likely future demographic development in the world. (4) Finally, as our analysis of zero population growth in the Jones (1995) model shows, falling growth rates need not mean that economic development grinds to a halt.

\section{Appendix}

This appendix derives the results reported for Case 4 in Section 3. The Hamiltonian for the control problem in Case 4 is:

$$
H=\frac{c^{1-\theta}-1}{1-\theta} L+\lambda_{1}(Y-c L)+\lambda_{2} \gamma A^{\varphi}(1-u) L,
$$

where $Y=A^{\sigma} K^{\alpha}(u L)^{1-\alpha}$, and $\lambda_{1}$ and $\lambda_{2}$ are the co-state variables associated with physical capital and knowledge, respectively. Necessary first order conditions (see Seierstad and Sydsaeter, 1987, p. 234) for an interior solution are:

$$
\begin{aligned}
& \frac{\partial H}{\partial c}=c^{-\theta} L-\lambda_{1} L=0, \\
& \frac{\partial H}{\partial u}=\lambda_{1}(1-\alpha) \frac{Y}{u}-\lambda_{2} \gamma A^{\varphi} L=0, \\
& \frac{\partial H}{\partial K}=\lambda_{1} \alpha \frac{Y}{K}=-\dot{\lambda}_{1}, \\
& \frac{\partial H}{\partial A}=\lambda_{1} \sigma \frac{Y}{A}+\lambda_{2} \varphi \gamma A^{\varphi-1}(1-u) L=-\dot{\lambda}_{2} .
\end{aligned}
$$

Combining (11) and (13) gives the Keynes-Ramsey rule

$$
\frac{\dot{c}}{c}=\frac{1}{\theta} \alpha A^{\sigma} K^{\alpha-1}(u l)^{1-\alpha} .
$$

Given the definition $p=\lambda_{2} / \lambda_{1},(12),(13)$ and (14) yield

$$
\frac{\dot{p}}{p}=\alpha A^{\sigma} K^{\alpha-1}(u l)^{1-\alpha}-\frac{\sigma \gamma A^{\varphi-1} u L}{1-\alpha}-\varphi \gamma A^{\varphi-1}(1-u) L .
$$


Let $x \equiv p A / K$. Log-differentiating $x$ w.r.t. time and using (12), (6), (5) and (4) give (7). Log-differentiating (12) w.r.t. time, using (16), (5), (4) and (6), gives (8). Finally, log-differentiating $1-s \equiv c L / Y$, using (15), (4), (6) and $(5)$, gives $(9)$.

Due to non-concavity of the maximized Hamiltonian, not all the Arrow sufficiency conditions (Seierstad and Sydsaeter 1987, p. 236) hold, and so far we have found no alternative set of sufficient conditions satisfied. Yet, at least the transversality conditions, $\lim _{t \rightarrow \infty} \lambda_{1}(t) K(t)=0$ and $\lim _{t \rightarrow \infty} \lambda_{2}(t) A(t)=0$, can be shown to hold along the unique regular growth path if (and only if) $\theta>(\sigma+1-\varphi) /[\sigma+\alpha(1-\varphi)]$.

\section{References}

[1] Alvarez-Pelaez, M. J., and C. Groth, 2005. Too Little or Too Much R\&D? European Economic Review 49, 437-456.

[2] Arnold, L., 2006. The Dynamics of the Jones R\&D Growth Model. Review of Economic Dynamics 9, 143-52.

[3] Asheim, G.B., Buchholz, W., Hartwick, J. M., Mitra, T., Withagen, C.A., 2005. Constant Savings Rates and Quasi-Arithmetic Population Growth under Exhaustible Resource Constraints. CESifo Working Paper No. 1573.

[4] Blanchard, O. J., Fischer, S., 1989. Lectures on Macroeconomics. MIT Press, Cambridge MA.

[5] Dasgupta, P., Heal G., 1979. Economic Theory and Exhaustible Resources. Cambridge University Press, Cambridge.

[6] Hartwick, J. M., 1977. Intergenerational Equity and the Investing of Rents from Exhaustible Resources. American Economic Review 67, 972974 .

[7] Jones, C. I., 1995. R\&D-based models of economic growth. Journal of Political Economy 103, 759-784.

[8] Jones, C. I., 2005. Growth and Ideas, in Handbook of Economic Growth, Elsevier, Amsterdam.

[9] Mitra, T., 1983. Limits on Population Growth under Exhaustible Resource Constraints, International Economic Review 24, 155-168. 
[10] Pezzey, J., 2004. Exact measures of income in a hyperbolic economy. Environment and Development Economics 9, 473-484.

[11] Ramsey, F. P., 1928. A Mathematical Theory of Saving. The Economic Journal 38, 543-559.

[12] Romer, P. M., 1990. Endogenous technological change. Journal of Political Economy 98, 71-101.

[13] Seierstad, A., Sydsaeter, K., 1987. Optimal Control Theory with Economic Applications. North Holland, Amsterdam.

[14] Solow, R. M., 1974. Intergenerational equity and exhaustible resources. Review of Economic Studies, Symposium Issue, 29-45.

[15] Solow, R.M., 1994. Perspectives on Growth Theory. Journal of Economic Perspectives 8, 45-54.

[16] Solow, R. M., 2000. Growth Theory, An Exposition. Oxford University Press, Oxford.

[17] United Nations, 2005. World Population Prospects. The 2004 Revision. New York.

[18] Young, A., 1998. Growth without Scale Effects, Journal of Political Economy 106, 41-63. 


\section{CESifo Working Paper Series}

(for full list see www.cesifo-group.de)

1637 Alfons J. Weichenrieder and Oliver Busch, Artificial Time Inconsistency as a Remedy for the Race to the Bottom, December 2005

1638 Aleksander Berentsen and Christopher Waller, Optimal Stabilization Policy with Flexible Prices, December 2005

1639 Panu Poutvaara and Mikael Priks, Violent Groups and Police Tactics: Should Tear Gas Make Crime Preventers Cry?, December 2005

1640 Yin-Wong Cheung and Kon S. Lai, A Reappraisal of the Border Effect on Relative Price Volatility, January 2006

1641 Stefan Bach, Giacomo Corneo and Viktor Steiner, Top Incomes and Top Taxes in Germany, January 2006

1642 Johann K. Brunner and Susanne Pech, Optimum Taxation of Life Annuities, January 2006

1643 Naércio Aquino Menezes Filho, Marc-Andreas Muendler and Garey Ramey, The Structure of Worker Compensation in Brazil, with a Comparison to France and the United States, January 2006

1644 Konstantinos Angelopoulos, Apostolis Philippopoulos and Vanghelis Vassilatos, RentSeeking Competition from State Coffers: A Calibrated DSGE Model of the Euro Area, January 2006

1645 Burkhard Heer and Bernd Suessmuth, The Savings-Inflation Puzzle, January 2006

1646 J. Stephen Ferris, Soo-Bin Park and Stanley L. Winer, Political Competition and Convergence to Fundamentals: With Application to the Political Business Cycle and the Size of Government, January 2006

$1647 \mathrm{Yu}-\mathrm{Fu}$ Chen, Michael Funke and Kadri Männasoo, Extracting Leading Indicators of Bank Fragility from Market Prices - Estonia Focus, January 2006

1648 Panu Poutvaara, On Human Capital Formation with Exit Options: Comment and New Results, January 2006

1649 Anders Forslund, Nils Gottfries and Andreas Westermark, Real and Nominal Wage Adjustment in Open Economies, January 2006

1650 M. Hashem Pesaran, Davide Pettenuzzo and Allan G. Timmermann, Learning, Structural Instability and Present Value Calculations, January 2006 
1651 Markku Lanne and Helmut Luetkepohl, Structural Vector Autoregressions with Nonnormal Residuals, January 2006

1652 Helge Berger, Jakob de Haan and Jan-Egbert Sturm, Does Money Matter in the ECB Strategy? New Evidence Based on ECB Communication, January 2006

1653 Axel Dreher and Friedrich Schneider, Corruption and the Shadow Economy: An Empirical Analysis, January 2006

1654 Stefan Brandauer and Florian Englmaier, A Model of Strategic Delegation in Contests between Groups, January 2006

1655 Jan Zápal and Ondřej Schneider, What are their Words Worth? Political Plans and Economic Pains of Fiscal Consolidations in New EU Member States, January 2006

1656 Thiess Buettner, Sebastian Hauptmeier and Robert Schwager, Efficient Revenue Sharing and Upper Level Governments: Theory and Application to Germany, January 2006

1657 Daniel Haile, Abdolkarim Sadrieh and Harrie A. A. Verbon, Cross-Racial Envy and Underinvestment in South Africa, February 2006

1658 Frode Meland and Odd Rune Straume, Outsourcing in Contests, February 2006

1659 M. Hashem Pesaran and Ron Smith, Macroeconometric Modelling with a Global Perspective, February 2006

1660 Alexander F. Wagner and Friedrich Schneider, Satisfaction with Democracy and the Environment in Western Europe - a Panel Analysis, February 2006

1661 Ben J. Heijdra and Jenny E. Ligthart, Fiscal Policy, Monopolistic Competition, and Finite Lives, February 2006

1662 Ludger Woessmann, Public-Private Partnership and Schooling Outcomes across Countries, February 2006

1663 Topi Miettinen and Panu Poutvaara, Political Parties and Network Formation, February 2006

1664 Alessandro Cigno and Annalisa Luporini, Optimal Policy Towards Families with Different Amounts of Social Capital, in the Presence of Asymmetric Information and Stochastic Fertility, February 2006

1665 Samuel Muehlemann and Stefan C. Wolter, Regional Effects on Employer Provided Training: Evidence from Apprenticeship Training in Switzerland, February 2006

1666 Laszlo Goerke, Bureaucratic Corruption and Profit Tax Evasion, February 2006

1667 Ivo J. M. Arnold and Jan J. G. Lemmen, Inflation Expectations and Inflation Uncertainty in the Eurozone: Evidence from Survey Data, February 2006 
1668 Hans Gersbach and Hans Haller, Voice and Bargaining Power, February 2006

1669 Françoise Forges and Frédéric Koessler, Long Persuasion Games, February 2006

1670 Florian Englmaier and Markus Reisinger, Information, Coordination, and the Industrialization of Countries, February 2006

1671 Hendrik Hakenes and Andreas Irmen, Something out of Nothing? Neoclassical Growth and the 'Trivial' Steady State, February 2006

1672 Torsten Persson and Guido Tabellini, Democracy and Development: The Devil in the Details, February 2006

1673 Michael Rauber and Heinrich W. Ursprung, Evaluation of Researchers: A Life Cycle Analysis of German Academic Economists, February 2006

1674 Ernesto Reuben and Frans van Winden, Reciprocity and Emotions when Reciprocators Know each other, February 2006

1675 Assar Lindbeck and Mats Persson, A Model of Income Insurance and Social Norms, February 2006

1676 Horst Raff, Michael Ryan and Frank Staehler, Asset Ownership and Foreign-Market Entry, February 2006

1677 Miguel Portela, Rob Alessie and Coen Teulings, Measurement Error in Education and Growth Regressions, February 2006

1678 Andreas Haufler, Alexander Klemm and Guttorm Schjelderup, Globalisation and the Mix of Wage and Profit Taxes, February 2006

1679 Kurt R. Brekke and Lars Sørgard, Public versus Private Health Care in a National Health Service, March 2006

1680 Dominik Grafenhofer, Christian Jaag, Christian Keuschnigg and Mirela Keuschnigg, Probabilistic Aging, March 2006

1681 Wladimir Raymond, Pierre Mohnen, Franz Palm and Sybrand Schim van der Loeff, Persistence of Innovation in Dutch Manufacturing: Is it Spurious?, March 2006

1682 Andrea Colciago, V. Anton Muscatelli, Tiziano Ropele and Patrizio Tirelli, The Role of Fiscal Policy in a Monetary Union: Are National Automatic Stabilizers Effective?, March 2006

1683 Mario Jametti and Thomas von Ungern-Sternberg, Risk Selection in Natural Disaster Insurance - the Case of France, March 2006

1684 Ken Sennewald and Klaus Waelde, "Itô's Lemma" and the Bellman Equation for Poisson Processes: An Applied View, March 2006 
1685 Ernesto Reuben and Frans van Winden, Negative Reciprocity and the Interaction of Emotions and Fairness Norms, March 2006

1686 Françoise Forges, The Ex Ante Incentive Compatible Core in Exchange Economies with and without Indivisibilities, March 2006

1687 Assar Lindbeck, Mårten Palme and Mats Persson, Job Security and Work Absence: Evidence from a Natural Experiment, March 2006

1688 Sebastian Buhai and Coen Teulings, Tenure Profiles and Efficient Separation in a Stochastic Productivity Model, March 2006

1689 Gebhard Kirchgaessner and Silika Prohl, Sustainability of Swiss Fiscal Policy, March 2006

1690 A. Lans Bovenberg and Peter Birch Sørensen, Optimal Taxation and Social Insurance in a Lifetime Perspective, March 2006

1691 Moritz Schularick and Thomas M. Steger, Does Financial Integration Spur Economic Growth? New Evidence from the First Era of Financial Globalization, March 2006

1692 Burkhard Heer and Alfred Maussner, Business Cycle Dynamics of a New Keynesian Overlapping Generations Model with Progressive Income Taxation, March 2006

1693 Jarko Fidrmuc and Iikka Korhonen, Meta-Analysis of the Business Cycle Correlation between the Euro Area and the CEECs, March 2006

1694 Steffen Henzel and Timo Wollmershaeuser, The New Keynesian Phillips Curve and the Role of Expectations: Evidence from the Ifo World Economic Survey, March 2006

1695 Yin-Wong Cheung, An Empirical Model of Daily Highs and Lows, March 2006

1696 Scott Alan Carson, African-American and White Living Standards in the $19^{\text {th }}$ Century American South: A Biological Comparison, March 2006

1697 Helge Berger, Optimal Central Bank Design: Benchmarks for the ECB, March 2006

1698 Vjollca Sadiraj, Jan Tuinstra and Frans van Winden, On the Size of the Winning Set in the Presence of Interest Groups, April 2006

1699 Martin Gassebner, Michael Lamla and Jan-Egbert Sturm, Economic, Demographic and Political Determinants of Pollution Reassessed: A Sensitivity Analysis, April 2006

1700 Louis N. Christofides and Amy Chen Peng, Major Provisions of Labour Contracts and their Theoretical Coherence, April 2006

1701 Christian Groth, Karl-Josef Koch and Thomas M. Steger, Rethinking the Concept of Long-Run Economic Growth, April 2006 